Uludag Univ. J. Fac. Vet. Med.

35 (2016), 1,2: 25-30

\title{
Yağlı Diyetle Beslenen Farelerin Karaciğer Dokusunda Magnezyumun Nitrik Oksit, Malondialdehit ve Glutatyon Düzeylerine Etkisi
}

\author{
Gülşah CESURER \\ Ayla ÖZCAN ${ }^{1}$
}

\begin{abstract}
Özet: Bu çalışmada yağlı diyetle beslenen farelerin karaciğer dokusunda, canlı organizma için birçok faaliyette görev alan magnezyumun nitrik oksit (NO), malondialdehit (MDA) ve glutatyon (GSH) düzeylerine etkisinin araştırılması amacıyla, 39 adet 2 aylık Swiss albino cinsi erkek fare kullanılmıştır. Fareler 4 gruba ayrılarak vücut ağılıkları tartıldı ve kaydedildi. Grup I standart pelet yem ve içme suyu, Grup II \% 31.5 yağ içeren pelet yem ve içme suyu, Grup III \% 31.5 yağ içeren pelet yem ve Mg ilaveli su, Grup IV standart pelet yem ve Mg ilaveli su ile 12 hafta süreyle beslendi. Vücut ağırlıkları tartıldıktan sonra anestezi işlemi gerçekleştirildi. Ötenazi işleminden sonra karaciğer dokularından $0.5 \mathrm{~g}$ parçalar alındı ve homojenize edildi. Elde edilen süpernatantlarda NO, MDA, GSH ve Mg analizleri yapıldı. Çalışmanın sonunda Grup I, Grup II ve Grup III'ün ilk ve son ağırlıkları arasında istatistiksel olarak anlamlı fark $(\mathrm{p}<0.01)$ gözlendi. Yağlı diyet verilen grubun NO düzeyleri kontrol grubuna göre ( $\mathrm{p}<0.001)$, yağlı diyet ve $\mathrm{Mg}$ verilen grubun $\mathrm{NO}$ düzeyleri, standart pelet yem ve $\mathrm{Mg}$ verilen gruba göre artış( $p<0.001)$ gösterdi. Yağlı diyet verilen grubun $\mathrm{Mg}$ düzeyi kontrol grubuna göre $(\mathrm{p}<0,001)$, yağlı diyet ve $\mathrm{Mg}$ verilen grubun $\mathrm{Mg}$ düzeyi standart pelet yem ve $\mathrm{Mg}$ verilen gruba göre düşük $(\mathrm{p}<0.001)$ bulundu. Yağlı diyet ile beslenen grup ile yağlı diyet ve Mg ile beslenen grupta MDA değeri $(p<0,001)$,standart pelet yem ve $\mathrm{Mg}$ verilen grubun GSH düzeyleri kontrol grubuna göre önemli artı̧ $(\mathrm{p}<0.001)$ göstermiştir.

Sonuç olarak yağlı diyet MDA ve NO düzeylerinde artışa, GSH düzeylerinde de bir azalmaya neden olmuştur. Yağlı diyete bağlı olarak MDA ve NO düzeylerinin normal seviyelere düşürülmesi bakımından Mg uygulamasının alternatif bir yöntem olarak kullanılabileceği kanaatine varıldı.
\end{abstract}

Anahtar Kelimeler: GSH, MDA, Mg, NO, Obezite, Yağlı diyet.

\section{The effect of Magnesium on Nitric Oxide, Malondialdehyde and Glutathione in Mice Liver Tissue Fed on Fat-Diet}

\begin{abstract}
In this study which aimed to investigate the effect on glutathione (GSH), nitric oxide (NO) and malondialdehyde (MDA) levels of magnesium (Mg) playing a role in many activities for the living organism in liver tissue of mice fed with fat diet, 39 2-month Swiss albino mice were used. Mice were divided into 4 groups by weighing their bodies. Group I was fed with standart pellet food and drinking water, Group II was fed with the diet containing $31.5 \%$ oil and drinking water, Group III was fed with the diet containing $31.5 \%$ oil and drinking water containing $7.5 \mathrm{~g} / \mathrm{L}$ magnesium sulphate $\left(\mathrm{MgSO}_{4}\right)$, Group IV was fed with standart pellet food and drinking water containing $7.5 \mathrm{~g} / \mathrm{L} \mathrm{MgSO}_{4}$ for 12 weeks. After weighing, anesthesia was pased. After euthanasia, $0.5 \mathrm{~g}$ from every liver tissue pieces were homogenized. The obtained supernatant NO, MDA, GSH and Mg analyzes were performed. At the end of the study, while the difference between the initial and the final weight of Group I, Group II and Group III was significant statistically $(\mathrm{p}<0.01)$. Compared to the control group, NO levels of the group fed with a fatty diet increased $(\mathrm{p}<0.001)$, and compared to the group fed with standart pellet food and Mg, NO levels of the group fed with a fatty diet and Mg increased $(\mathrm{p}<0.001)$. Compared to the control group, it was determined that there was a significant decrease $(\mathrm{p}<0.05)$ in the $\mathrm{Mg}$ level of the group fed with a fatty, and compared to the group fed with standart pellet food and Mg, it was determined that there was a signifi-
\end{abstract}

1 Kafkas Üniversitesi Tıp Fakültesi, Tıbbi Biyokimya Anabilim Dalı, KARS aylabicer@hotmail.com 
cant decrease $(\mathrm{p}<0,05)$ in the Mg level of the group fed a fatty diet and Mg. MDA levels increased in the group fed with fat diet and in the group fed with fat diet and Mg, and compared to the control group, GSH levels of the group of fed standard pellet food and $\mathrm{Mg}$ significantly increased $(\mathrm{p}<0.001)$. Consequently, fat diet caused an increase in MDA and NO levels and a decrease in GSH levels. Depending on a fatty diet, it was reached the conclusion that Mg implementation could use as an alternative method in terms of that increasing NO and MDA levels decrease to normal levels.

Key Words: Fat Diet, GSH, MDA, Mg, NO, Obesity.

\section{Giriş}

Genel olarak bedenin yağ kütlesinin yağsız kütleye oranının aşırı artması sonucu boy uzunluğuna göre vücut ağırlığının istenilen düzeyin üstüne çıkması şeklinde tanımlanan obezite, aşırı yağ depolanmasından kaynaklanmaktadır ve oksidatif stres tarafindan etkilenmekte$\operatorname{dir}^{15,22}$.

Oksidatif stres, oksidan ve anti-oksidan sistemler arasındaki dengenin oksidan sistemler lehine bozulması sonucu lipid peroksidasyonu ve buna bağlı olarak reaktif oksijen türlerinin (ROT) açığa çıkarak organizmada hücresel hasara yol açması şeklinde tanımlanabilir ve birçok hastalıkta kritik öneme sahiptir ${ }^{8}$. Geniş vücut kütlesinden kaynaklanan basınç nedeniyle ortaya çıkan progresif ve kümülatif hücre hasarı tümor nekroz faktör alfa (TNF- $\alpha$ ) başta olmak üzere ceşitli sitokinlerin salınımına yol açar ve bu durum dokularda ROT açığa çıkmasına neden olabiliir ${ }^{18}$. Başka olası mekanizmalardan birisi de diyetle antioksidan kapasiteyi aşacak miktarda serbest yağ asidi alımı lipid peroksidasyonuna yol açarak oksidatif stresi uyarabi$\operatorname{lir}^{18}$. Adipositler ve çevrelerindeki bağ dokusundan salınan adipokin veya adipositokin (leptin-adiponektin) olarak isimlendirilen moleküllerin vücutta kronik inflamasyona ve oksidatif strese yol açacak sinyalleri uyardığı kaydedilmiştir ${ }^{9,11,15,17,21}$.

Nitrik oksitin (NO) LDL oksidasyonu üzerine peroksinitrit aracilığıla prooksidan veya ROT'nin şelasyonu yolu ile antioksidan etkisi olup, bu etki ortamın pH'1 ve ROT konsantrasyonu gibi çevresel sartlara göre değişmektedir ${ }^{5,7}$. Lipit peroksidasyonu sonucu oluşan en sitotoksik ürünler, aldehitlerdir. Malondialdehit (MDA), lipit peroksitlerin enzimatik olmayan oksidatif parçalanma ürünüolup, hücre zarından kolayca geçebildiği için hücre içindeki yapıları olumsuz etkilemekte ve deformasyona neden olmaktadır. Yüksek yağlı diyetin obezitenin yanı sıra karaciğer yağlanmasına da neden olduğu bildirilmiştir ${ }^{1}$. Önemli bir indirgeyici ajan ve antioksidan olan glutatyon (GSH) hüc- renin oksido-redüksiyon dengesini sürdürüp, hücreleri endojen ve ekzojen kaynaklı oksidanların zararlı etkilerinden korumaktadır ${ }^{24}$. GSH askorbik asit metabolizmasını, hücreler arası iletişimin sürdürülmesini sağlayan ve genel olarak proteinlerin sülfidril (-SH) gruplarının okside olmasını ve çapraz bağlanmasını engelleyen diğer birçok metabolik süreçte yer almaktadır ${ }^{13}$.

Bu çalışmada canlılar üzerinde çok sayıda olumlu etkileri olan, eksikliğinde ise çeşitli hastalıklara zemin hazırlayan magnezyumun yağlı diyetle beslenmiş farelerde GSH, MDA ve NO düzeyleri üzerine etkisinin araştırılması amaçlanmıştır.

\section{Materyal ve Metot}

$\mathrm{Bu}$ çalışmada Atatürk Üniversitesi Deneysel Hayvan Laboratuvarından temin edilen ve Atatürk Üniversitesi Hayvan Deneyleri Yerel Etik Kurul'unca kullanılması onaylanan, vücut ağırlıkları $34.36 \pm 4 \mathrm{~g}$ olan 39 adet Swiss albino cinsi erkek fare materyal olarak kullanıldı. Kafkas Üniversitesi Deney Hayvanları Araştırma, Barındırma ve Uygulama Merkezine getirilerek 15 gün boyunca adaptasyona alındı. Çalışma süresince fareler, diürnal 1şık şartlarında (12 saat sürekli aydınlık, 12 saat sürekli karanlık), $\% 40$ nem oran 1 ve $22^{0} \mathrm{C}$ sicaklık bulunan bir ortamda tutuldu. Bu farelerden rastgele seçilerek 4 grup oluşturuldu. Farelerin vücut ağırlıklar1 tartılarak kaydedildi.

Grup I (Kontrol): Standart pelet yem ve içme suyu adlibitum olarak verildi $(\mathrm{n}=10)$.

Grup II: Yağlı diyet (\% 31.5 hayvansal yağ içeren diyet) ve içme suyu adlibitum olarak verildi $(\mathrm{n}=10)$.

Grup III: Yağlı diyet (\% 31.5 hayvansal yağ içeren diyet) ve magnezyum ilaveli su adlibitum olarak verildi $(\mathrm{n}=10)$.

Grup IV: Standart pelet yem ve magnezyum ilaveli su adlibitum olarak verildi $(\mathrm{n}=9)$.

12 haftalık uygulama sonrası fareler tekrar tartıldı ve vücut ağırlıkları kaydedildi. Anestezi edilen hayvanlardan ötenazi işlemini izleye- 
rek alınan karaciğer doku örnekleri hemen serum fizyolojik ile yıkanarak kan ve diğer dokulardan temizlendi ve alüminyum folyo ile paketlenerek iki hafta süreyle $-20^{\circ} \mathrm{C}$ 'de saklandı.

Analiz edilmek üzere dokuların soğukluğu muhafaza edilerek cerrahi makasla her bir dokudan $0.5 \mathrm{~g}$ parçalar alındı. Çalışmada kullanılan tüm solüsyonlar günlük olarak hazırland1. Cam tüpe aktarılan dokular üzerine $5 \mathrm{ml}$ fosfat tamponu ( $\mathrm{pH}$ 7.4) eklendi. Buz doldurulmuş plastik kap içerisine yerleştirilen cam tüpteki doku homojenizatörde 16000 devir/dk hizda homojenize edildi. Homojenatlar 3000 devirde $15 \mathrm{dk}$ santrifüj edildi ve süpernatantlarda NO, MDA, GSH ve Mg analizleri yapıldı.

NO tayini Miranda ve ark.'nın (2001), MDA tayini Yoshioka ve ark.'nın (1979), GSH tayini Beutler ve ark.'nın (1963) bildirdikleri yöntemle tayin edildi. Magnezyum düzeylerinin ölçümü için Sigma-Aldrich ${ }^{\circledR}$ Magnezyum kiti (Katalog No: MAK026) kullanıldı.

\section{Bulgular}

Çalışmanın sonunda vücut ağırlıkları bakımından Grup I, Grup II ve Grup III'ün ilk ve son ağırlıkları arasında istatistiksel olarak anlamlı fark $(\mathrm{p}<0.01)$ gözlenirken Grup IV’nin ilk ve son ağırlıkları arasında istatistiksel olarak fark bulunamadi.

Yağlı diyet verilen grubun NO düzeyi kontrol grubuna göre, yağlı diyet ve $\mathrm{Mg}$ verilen grubun NO düzeyi standart pelet yem ve $\mathrm{Mg}$ verilen gruba göre istatistiksel olarak önemli artış $(p<0.001)$ göstermiştir. Yağlı diyet ve $\mathrm{Mg}$ verilen grubun NO düzeyi kontrol grubunun seviyelerine yakın olarak bulunmuştur (Şekil 1).

Yağlı diyet ile beslenen grubun ve yağlı diyet ile $\mathrm{Mg}$ verilen grubun değerleri kontrol grubuna göre artış $(\mathrm{p}<0.001)$ göstermiştir. Yağl1 diyet ve $\mathrm{Mg}$ verilen grupta istatistiksel açıdan önemli artış ( $\mathrm{p}<0.001)$ görülmüştür (Şekil 2).

Yağlı diyet ile beslenen grup ile yağlı diyet ve $\mathrm{Mg}$ ile beslenen grubun GSH düzeyi kontrol grubuna göre düşüş göstermesine rağmen istatistiksel olarak anlamlı değildir. $\mathrm{Mg}$ verilen grubun GSH düzeyleri yağlı diyet ve $\mathrm{Mg}$ verilen gruba göre istatistiksel olarak anlamlı $\operatorname{artış~(~} \mathrm{p}<0.001)$ göstermiştir (Şekil 3).

Yağlı diyet verilen grubun $\mathrm{Mg}$ düzeyi kontrol grubuna göre $(p<0,001)$, yağlı diyet ve $\mathrm{Mg}$ verilen grubun $\mathrm{Mg}$ düzeyleri normal diyet ve $\mathrm{Mg}$ verilen gruba göre istatistiksel olarak anlamlı düşme ( $\mathrm{p}<0.001)$ göstermiştir (Şekil 4).

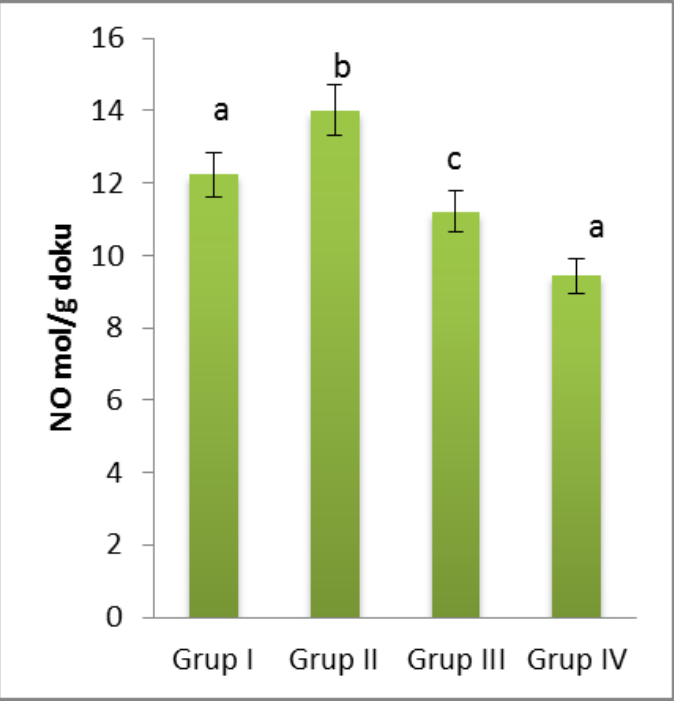

Şekil 1. NO düzeyleri

Figure 1. NO levels

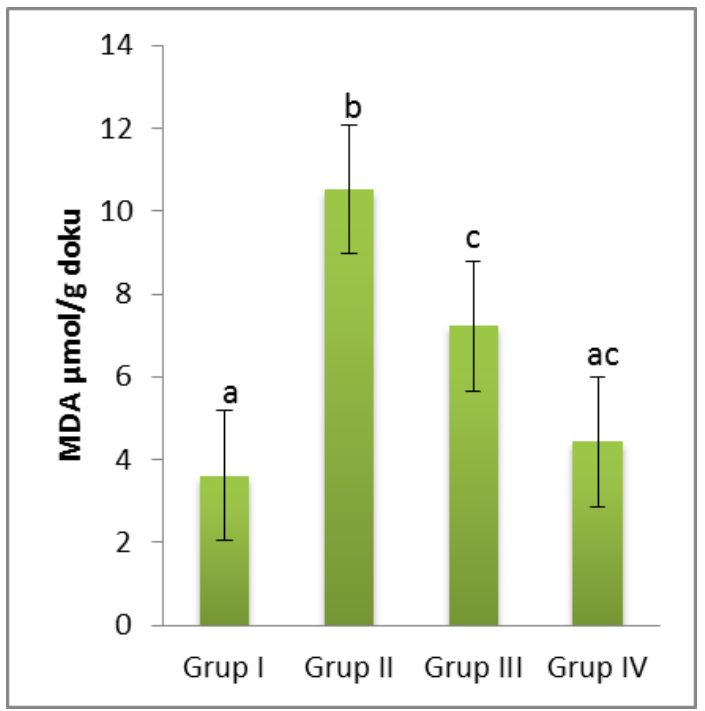

Şekil 2. MDA düzeyleri

Figure 2. MDA levels

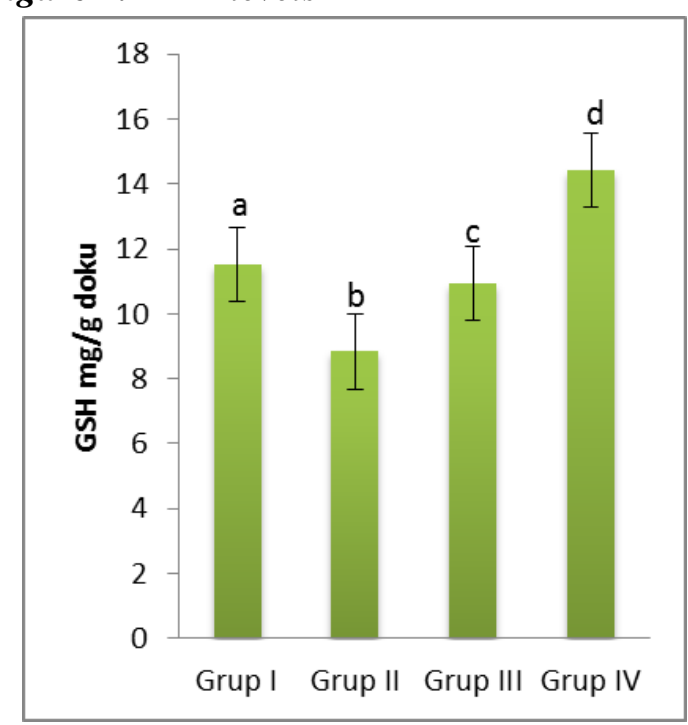

Şekil 3. GSH düzeyleri

Figure 3. GSH levels 


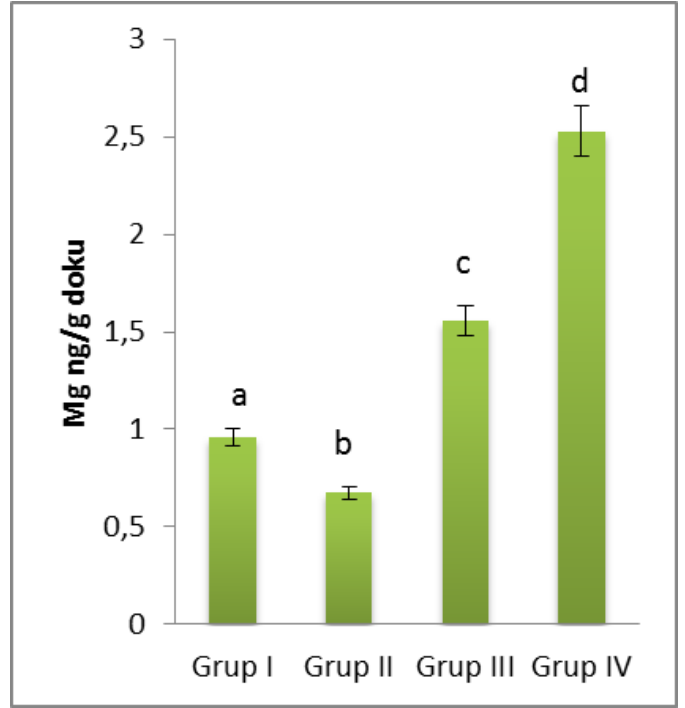

Şekil 4. Mg düzeyleri

Figure 4. Mg levels

\section{Tartışma ve Sonuç}

Yapılan birçok çalışmada normal diyete yaklaşık \% 10 ile \% 46 arasında değişen oranlarda tereyağ 1 , domuz yağ 1 ve sığır etinden elde edilen don yağ gibi hayvansal yağlar eklenerek 6-20 hafta arasında değişen sürelerde beslenen fare ve ratlarda canlı ağırlığının lipit birikimiyle bağlantılı olarak arttığı belirlenmiştir ${ }^{27,28}$. Yap1lan araştırmada da yağlı diyet verilen grubun canlı ağırlığındaki artışın, lipogenez ve lipit birikiminden kaynaklanabileceği kanısına varilmıştır ${ }^{20,27}$.

NO’nun ilk olarak lipoliz düzenlenmesinde ikinci olarak obezitede düşük lipoliz oranlarının gösterilmesinde rol oynadığını ancak NO’nun bu rolünün açıklanabilmesi için daha fazla çalışma yapılması gerektiğini belirtmişler$\operatorname{dir}^{7}$. Choi ve ark. (2001) ile Higashi ve ark. (2003) obez insanlarda VKİ'deki artışla serum NO konsantrasyonundaki artışın paralel olduğunu göstermişlerdir. Benzer şekilde yapılan çalışmada yağlı diyet verilen grubun NO seviyesindeki artışın, VKİ'deki artışa bağlı olabileceği düşünülmektedir.

MDA lipit peroksidasyonu sonucu ortaya çıkan, son ürün olup, proteinlerin amino gruplarına, fosfolipidler veya nükleik asitlere bağlanarak toksik etki göstermektedir. Davi ve ark. (2002) abdominaldeki yağ birikimi ile lipit peroksidasyonu arasında ilişki olduğunu belirtirken, Yılmaz ve ark. (2007) obez çocuklarda yaptıkları çalıșmada MDA seviyelerini kontrol grubuna göre yüksek bulmuşlardır. Ghosh ve ark. (2011) obezite oluşturulan farelerin karaci- ğer dokusunda MDA değerlerinin kontrol grubuna göre yüksek olduğunu gözlemlemişlerdir. Günyaktı (2000), ratlarda yaptığı çalışmasında; doymuş bir yağ olmasına rağmen margarinin lipid peroksidasyonuna dirençli olmadığı ve tereyağının yüksek kolesterol içeriğine rağmen lipid peroksidasyonuna dirençli olduğunu göstermiştir. Yapılan çalışmada da yağlı diyet verilen grubun MDA düzeyindeki artışın lipid peroksidasyonu ve dolayısiyla oksidatif stres ile bağlantılı olabileceği düşünülmektedir ${ }^{25}$.

Seyithanoğlu ve ark. (2012) yüksek yağlı diyetle beslenen farelerde karaciğer GSH düzeyinin değişmediğini kaydetmişlerdir. Günyaktı (2000), rasyona yağ ilavesi ile beslenen ratlarda yaptığ karaciğer ve eritrosit GSH değerleri arasında önemli bir fark belirleyememiştir. Benzer şekilde yapılan bu çalışmada yağlı diyet verilen grubun GSH seviyesi kontrol grubuna yakın bulunmuştur.

Yapılan bir araştırmada ${ }^{19}, \mathrm{Mg}$ eksikliğinin, GSH ve vitamin E düzeylerinde düşmeye, MDA düzeylerinde artışa yol açtığı ve antioksidanların, Mg eksikliğinde ortaya çıkan prooksidan etkilere karşı rolü olabileceği kanaatine varılmıștır. Huerta ve ark. (2005) ile Jose ve ark. (2011) obez çocuklarda Mg düzeylerinin düşük olduğunu göstermişler ve insülin direncini arttırdığını kaydetmişlerdir. Benzer şekilde yapılan bu çalışmada da yağlı diyetle beslenen grupta $\mathrm{Mg}$ seviyesi kontrol grubuna göre düşük saptanmış olup, Mg'un GSH seviyesinde artışa NO ve MDA seviyesinde azalmaya neden olduğu görülmektedir. Bu durumla ilgili olarak bozulan antioksidan sistem ve artmış oksidatif stresin, Mg takviyesiyle düzeltilebileceği düşünülmektedir ${ }^{3}$.

$\mathrm{Bu}$ çalışmada farelerin karaciğerlerinden elde edilen histopatolojik bulgularda yağlı diyet verilen gruplarda karaciğer hücrelerinde değişik büyüklüklerde lipid vakuolleri, yağlı diyet ve Mg'li su verilen grupta ise daha küçük çaplı lipid vakuolleri saptanmıştır.

Sonuç olarak; Yağlı diyetle beslenen grubun canlı ağırlığındaki artışın lipit birikimi ile bağlantılı olabileceği ve Mg'un lipit birikimine ve oksidatif strese karşı olumlu etkisinin olabileceği, VKI'deki artışa bağlı olarak artan NO seviyesini ve antioksidan metabolizma üzerindeki olumlu etkiye bağlı olarak GSH düzeyini normale yaklaşacağı düşünülmektedir. 


\section{Kaynaklar}

1. Altunkaynak Z. Effects of high fat diet induced obesity on female rat livers (a histochemical study). Eur J Gen Med, (2005). 2(3): 100-109.

2. Beutler, E.. Duron, O.. Kelly, B.M. Improved method for determination of blood glutathione. J. Lab. Clin Med. (1963). 61: 882-888.

3. Capel ID, Dorrell HM. Abnormal antioxidant defense in some tissues of congenitally obese mice. Biochem J. (1994).,219: 41- 49, 14.

4. Choi JW, Pai SH, Kim SK, Ito M, Park CS, Cha YN. Increases in nitric oxide concentrations correlate strongly with body fat in obese humans. Clin Chem. (2001). 47(6):1106-9.

5. Cristol JP, Maggi MF, Guérin MC, Torreilles J, Descomps B. Nitric oxide and lipid peroxidation. C R Seances Soc Biol Fil, (1995). 189:797-809.

6. Davì G, Guagnano MT, Ciabattoni G, Basili S, Falco A, Marinopiccoli M, Nutini M, Sensi S, Patrono C. Platelet activation in obese women: role of inflammation and oxidant stress. JAMA. (2002). 23-30, 288(16): 2008-14.

7. Elizalde M, Rydén M, van Harmelen V, Eneroth P, Gyllenhammar H, Holm C, Ramel S, Olund A, Arner P, Andersson K. Expression of nitric oxide synthases in subcutaneous adipose tissue of nonobese and obese humans. J Lipid Res (2000). 41: 1244-51.

8. Fearon IM, Faux SP. Oxidative stress and cardiovascular disease: novel tools give (free) radical insight. J Mol Cell Cardiol; (2009). 47: 372-81.

9. Galic S, Oakhill JS, Steinberg GR. Adipose tissue as an endocrine organ. Mol Cell Endocrinol, (2010). 316: 129-39.

10. Ghosh S, Sulistyoningrum C.D, Glier B.M, Verchere B.C, Devlin M.A. Altered glutathione homeostasis in heart augments cardiac lipotoxicity associated with diet-induced obesity in mice. J Biolog Chem, (2011). 42483-42493.

11. Guerre-Millo M. Adipose tissue and adipokines: for better or worse. Diabetes Met. (2004). 30: 139.

12. Günyaktı A. Katı ve sıvı yağ tüketiminin karaciğerde glutatyon sentezi ve serbest radikal üretimi üzerine olan etkilerinin araştırılması, Yüksek Lisans Tezi, Selçuk Üniv Biyokimya (Tıp) AD, Konya. (2000).

13. Halliwell B, Gutteridge JMC. Free Radicals in Biology and Medicine, Third Edition, Oxford Science Publications, (2001). 22- 24

14. Higashi Y, Sasaki S, Nakagawa K, Kimura M, Noma K, Sasaki S. Low body mass index is a risk factor for impaired endothelium-dependent vasodilation in humans: Role of nitric oxide and oxidative stress. J Am Coll Cardiol. (2003). 42:256- 63
15. Higdon JV, Frei B. Obesity and oxidative stress: a direct link to CVD? Arterioscler Thromb Vasc Biol. (2003).23: 365-7.

16. Huerta MG, Roemmich JN, Kington ML, Bovbjerg VE, Wettman AL, Holmes YF, Magnesium deficiency is associated with insulin resistance in obese children: Diabetes Care (2005). 28:117581.

17. Kershaw EE, Flier JS. Adipose tissue as an endocrine organ. J Clin. Endocrinol Met., (2004). 89: 2548-56.

18. Khan NI, Naz L, Yasmeen G. Obesity: an independent risk factor for systemic oxidative stress. Pak J Pharm Sci, (2006). 19: 62-5.

19. Kharb S, Singh V. Magnesium deficiency potentiates free radical production associated with myocardial infarction. J Assoc Physicians India (2000). 48:484-5.

20. Lee JS, Lee MK, Ha TY, Bok SH, Park HM, Jeong KS, Woo MN, Do M, Yeo JY, Choi MS. Supplementation of whole persimmon leaf improves lipid profiles and suppresses body weight gain in rats fed high-fat diet. Food Chem Toxicol, (2006). 44 (11): 1875-83.

21. Matsubara M, Maruoka S, Katayose S. Inverse relationship between plasma adiponectin and leptin concentrations in normal-weight and obese women. Eur J Endocrinol, (2002). 147: 173-80.

22. Miller, D.D. Minerals. In "Food Chemistry", O.R. Fennema (Ed), pp: Marcel Dekker, New York. (1996). 617-649.

23. Miranda KM., Espey MG., Wink DA., A rapid, simple spectrophotometric method for simultaneous detection of nitrate and nitrite. Nitric Oxide., (2001).5, 62-71.

24. Olszanecka-Glinianowicz M, ZahorskaMarkiewicz B, Janowska J, Zurakowski A. Serum concentrations of nitric oxide, tumor necrosis factor (TNF)-alpha and TNF soluble receptors in women with overweight and obesity. Met (2004). 53:1268-73.

25. Özata, M, Mergenb M, Oktenli C, Aydin A, Sanisoglu SY, Bolu E, Yilmaz M.İ, Sayal A, Isimer Ozdemir C. Increased oxidative stress and hypozincemia in male obesity. Clin Biochem. (2002).35, 8, 627-631.

26. Seyithanoğlu M., Öner-İyidoğan Y., Koçak H., Koçak-Toker N., Uysal M. Yüksek yağlı diyetle beslenen farelerin karaciğerinde trigliserid düzeyleri ve oksidatif stres üzerine enginar yaprağ ekstresinin etkisi. Tr J.Biochem, (2012). 37.

27. Ryu MH, Cha YS. The effects of a high-fat or high-sucrose diet on serum lipid profiles, hepatic acyl-CoA synthetase, carnitine palmitoyltransferase-I, and the acetyl-CoA carboxylase mRNA levels in rats. J Biochem Mol Biol, (2003). 36 (3): 312-318 
28. Woods SC, D'alessio DA, Tso P, Rushing PA, Clegg DJ, Benoit SC, Gotoh K, Liu M, Seeley RJ. Consumption of a high-fat diet alters the homeostatic regulation of energy balance. Physiol Behavior, (2004). 83 (4): 573-578.

29. Yoshioka T., Kawada K., Shimada T., Mori M., Lipid peroxidation in maternal and cord blood and protective mechanism against activatedoxygen toxicity in the blood. Am. J. Obstet. Gynecol, (1979).135, 372-376.

30. Yilmaz A, Coban E, Sari R. The effect weight loss on the mean platelet volume in obese patients. Platelets (2007). 18 (3): 212-216. 